\section{Satsuma Mandarin Fruit Size Increased by 2,4-DP}

\author{
M. Agustí, V. Almela, and M. Aznar \\ Departamento de Producción Vegetal, Universidad Politécnica, 46020 \\ Valencia, Spain
}

\section{El-Otmani \\ Departement d'Horticulture, Institut Agronomique et Vétérinaire Hassan II, B.P. 121 Ait Melloul, 80800 Agadir, Morocco}

\section{J. Pons \\ Institut de Recerca i Tecnología Agroalimentáries, Centre Experimental de l'Ebre, Amposta, Spain}

Additional index words. auxin, yield, fruit growth, fruit quality, Citrus unshiu

\begin{abstract}
The butylglycol ester of 2,4-DP increased final fruit size in 'Owari Satsuma' mandarin (Citrus unshiu Marc.). The response magnitude depended on the concentration applied and treatment date. When applied at the end of physiological drop, $50 \mathrm{mg} \cdot \mathrm{liter}^{-1}$ was the most effective treatment for increasing fruit size. Peel density and firmness also were improved. Because no fruit thinning occurred, this auxin seemed to stimulate fruit growth. Chemical name used: 2,4-dichlorophenoxypropionic acid (2,4-DP).
\end{abstract}

Applying butylglycol ester of 2,4-DP just after physiological fruit drop increased significantly the final fruit size of 'Clementine' (Citrus reticulataBlanco) (Agustí et al., 1991a; Vanniere and Arcuset, 1989) and other mandarins (Almela et al., 1991) and sweet oranges [Citrus sinensis (L.) Osbeck] (Agustí et al., 1991b). The response increased linearly with increased concentration until an apparent optimum was reached at $\approx 75 \mathrm{mg} \cdot$ liter $^{-1}$ for 'Clementine Fina' (Agustí et al., 1991a) and 'Fortune' mandarin (Almela et al., 1991).

In comparison with the majority of synthetic auxins (Agustí and Almela, 1984; ElZeftawi, 1976; Guardiola et al., 1988; Suzuki and Hirose, 1977), 2,4-DP does not thin fruit as effectively (Agustí and Almela, 1991). This effect is most marked when 2,4-DP is applied shortly after physiological drop ( Agustí et al., 1991a; Almela et al., 1991; Vanniere and Arcuset, 1989). Currently, 2,4-DP can enhance mandarin and sweet orange fruit size better than naphthalene acetic acid (NAA) and 2,4,5-trichlorophenoxyacetic acid (2,4,5-T) (Agustí and Almela, 1991).

Although manual and chemical fruit thinning have a stimulator effect on fruit size in a Mediterranean climate, thinning is not economical unless it is done early in fruit development (Zaragoza et al., 1990) and is sufficient to reduce yield (Guardiola et al., 1982; Morioka

\footnotetext{
Received for publication 14 Apr. 1993. Accepted for publication 19 Oct. 1993. These experiments were supported by grants from Especialidades Técnico Industrials, Barcelona, Spain, through a collaborative agreement with Universidad Politécnica de Valencia (grants BVG2A1/642 and 89133BVG). The cost of publishing this paper was defrayed in part by the payment of page charges. Under postal regulations, this paper therefore must be hereby marked advertisement solely to indicate this fact.
}

by handgun at 6 liters/tree on whole trees after physiological drop. The concentrations used were $0,25,50,75$, and $100 \mathrm{mg} \cdot$ liter $^{-1}$ on Date 1 (15 July 1988) and 0, 25, and $50 \mathrm{mg} \cdot$ liter $^{-1}$ on Date 2 (1 Aug. 1988). A nonionic wetting agent (nonylphenyl-polyethylene glycol ether) at $0.01 \%$ was included in all treatments. We used a randomized complete-block design with two-tree plots of five replications each. Experiments were run for 3 years (1988-90).

Fruit size was evaluated at spray application and harvest by measuring the equatorial diameter of 30 randomly selected fruit from each tree. Their average and standard error were also determined.

Before harvest, 20-fruit samples were picked from each replication at $1.5-$ to $2.0-\mathrm{m}$ heights within all tree quadrants. Juice volume, peel weight, and the proportion of each relative to the whole fruit were determined. We used a rotary extractor (Nytor, Barcelona, Spain) to obtain juice. Juice total soluble solids concentration (SSC; ${ }^{\circ}$ Brix) was measured by a digital refractometer (ATAGO, Tokyo), and acid (A) concentration was determined by titration with $0.1 \mathrm{~N} \mathrm{NaOH}$. Peel firmness was determined by a Chatillon penetrometer using a 5-mm-diameter flat cylinder.

Fruit puffiness was evaluated by 1) packinghouse personnel who normally sort out puffy fruit by externally examining fruit and by 2 ) research staff who examined fruit internally for rind separation from the endocarp using a 50-fruit sample from each replication. Incidence of puffiness was calculated as puffy fruit counts/total fruit examined.

Average fruit weight was determined by weighing and counting the number of fruit per tree. Fruit size distribution was determined by commercial grading. Analysis of variance and regression were performed on the data.

\section{Results}

Date of application and concentration. The 2,4-DP application significantly increased fruit size. This effect was consistent from year to year (Table 1) and increased with increasing 2,4-DP concentration. Our maximum was 75 mg.liter ${ }^{-1}$ on Date 1 (Fig. 1). An increment of $\approx 4 \mathrm{~mm}$ in diameter per fruit was obtained with trees treated on Date 1 (i.e., when fruit diameter was $\approx 25 \mathrm{~mm}$ ).

Application date significantly affected the response. Mature fruit on trees treated with 25 or $50 \mathrm{mg} \cdot$ liter $^{-1}$ on Date 1 were significantly larger than those from trees treated with the same concentrations 15 days later $(\mathrm{F}=37.4 ; P$ $0.01)$. The concentration $x$ date interaction 
was statistically significant $(\mathrm{F}=14.9 ; P \leq$ 0.01). A 2,4-DP application at $50 \mathrm{mg} \cdot \operatorname{liter}^{-1}$ on Date 2 affected fruit growth about the same as $25 \mathrm{mg} \cdot$ liter $^{-1}$ applied immediately after physiological drop (Fig. 1). Influence of concentration and relationship between auxin concentration and treatment date is obvious; however, date was the most important factor.

Yield. Our treatments did not thin the fruit; therefore, the number of fruit per tree was not reduced by 2,4-DP (data not shown). Because of increased fruit weight, there was a slight increase in crop load on treated trees. Effects of 2,4-DP on fruit count and yield were consistent from year to year (data not shown).

The fruit-size response to 2,4-DP implies that the effect obtained did not depend on the number of fruit per tree. This conclusion becomes evident by comparing the regression lines between the number of fruit per tree and their average weight on the control trees and trees treated with $50 \mathrm{mg} \cdot$ liter $^{-1}$ on the first treatment date. The equations represent parallel lines (data not shown). The treatment's effect on fruit diameter distribution is more important than its effect on average fruit size. Fruit diameters for treated trees were larger (Fig. 2), indicating all fruit were affected by auxin.

Characteristics of treated fruit. The effect of 2,4-DP on the endocarp was significant. Increasing the auxin concentration increased the juice percentage and decreased the peel percentage. Correlations between these variables and 2,4-DP concentration were significant (Table 2).

Because total acid concentration per fruit was not significantly altered by our treatments, we concluded that the reduction in free acid concentration was a dilution effect from the increase in juice content of treated fruit. The SSCs were not affected by 2,4-DP; therefore, variations in the SSC : acid ratio appear to be due to those observed on free acid concentration.

The auxin also affected peel development. The 2,4-DP treatment increased peel weight per fruit (Table 2) without simultaneously increasing peel thickness (Table 3 ), thus producing a denser and firmer peel. As a consequence, puffiness, as determined externally, was reduced. This does not mean the puffing process was controlled; examining the fruit internally showed that the incidence of puffiness was not altered by the treatments (Table 3 ). Using 2,4-DP, however, presents a treatment that reduces the fruit's puffy external appearance.

\section{Discussion}

Treatment of 'Owari Satsuma' mandarin trees with the butylglycol ester of 2,4-DP at the end of physiological drop significantly increased final fruit size without altering the number of fruit per tree. This result indicates a direct stimulation of fruit growth. The temporary depressive effect on fruit growth, a phenomenon that occurs after the application of many synthetic auxins (Guardiola et al., 1988, 1993; Lewin and Monselise, 1976), was ab-

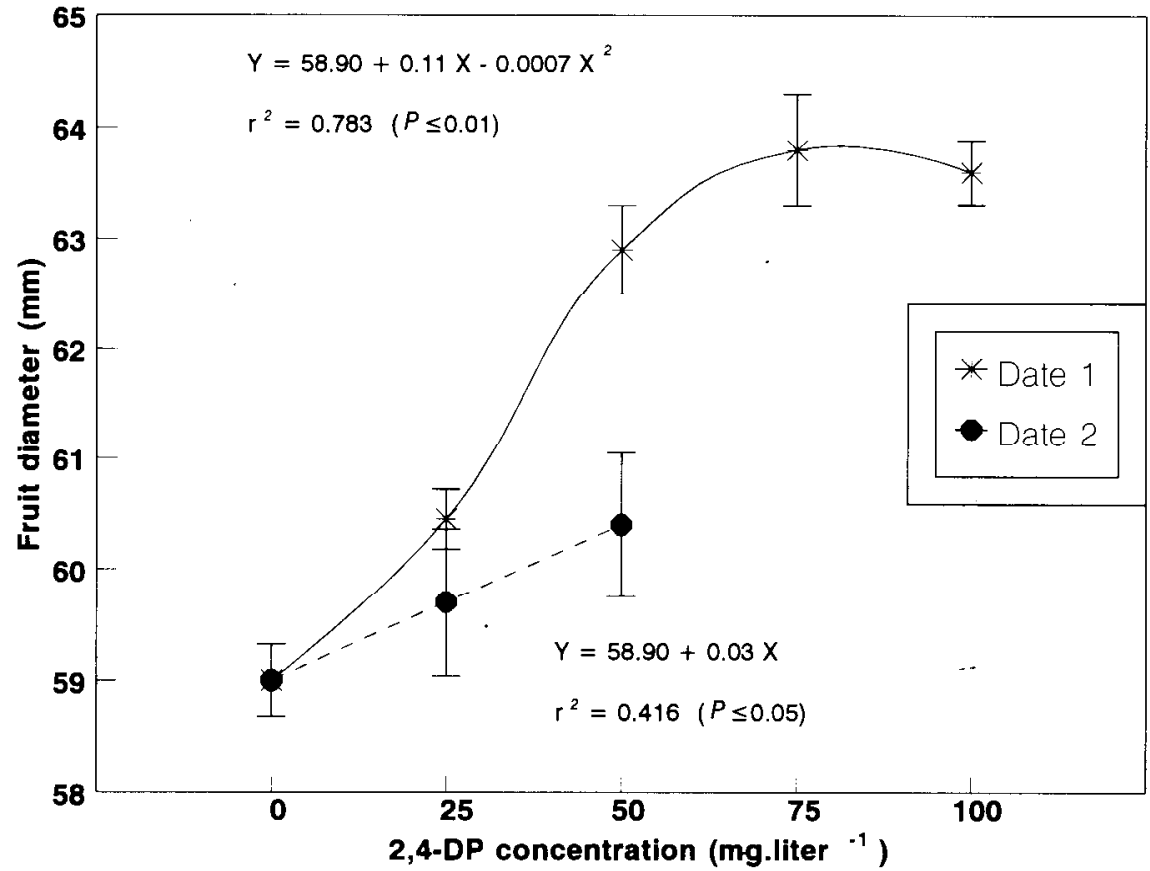

Fig. 1. Influence of 2,4-DP concentration and treatment date on fruit size of 'Owari Satsuma' mandarin at maturity in 1988. Fruit diameter at treatment on Date 1 was $25.1 \pm 0.4 \mathrm{~mm}$, and on Date 2 it was 30.7 $\pm 0.3 \mathrm{~mm}$, Standard errors are given as vertical bars.

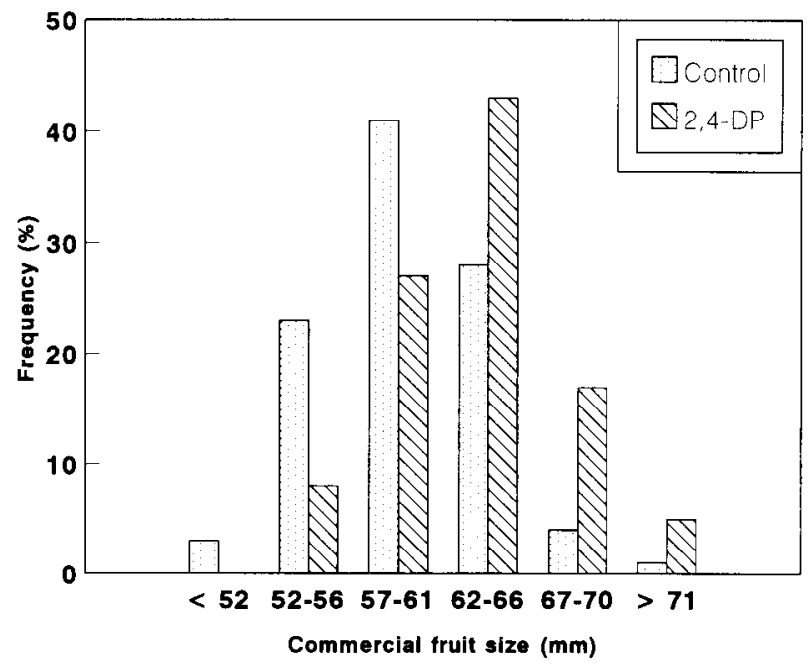

Fig. 2. Influence of 2,4-DP on frequency distribution of 'Owari Satsuma' mandarin fruit diameters at harvest. Average values of treated fruit correspond to 2,4-DP at 0 and $50 \mathrm{mg} \cdot$ liter $^{-1}$ on Date 1 (1988).

Table 2. Regression analysis of the response of several variables to 2,4-DP concentration $(\mathrm{X})^{\mathrm{z}}$.

\begin{tabular}{|c|c|c|c|}
\hline \multirow[b]{2}{*}{ Variable } & \multicolumn{2}{|c|}{$r$} & \multirow{2}{*}{$\begin{array}{c}\text { Regression } \\
\text { equation }\end{array}$} \\
\hline & Value & Significance & \\
\hline \multicolumn{4}{|l|}{ Fruit } \\
\hline Weight (g) & 0.591 & $* *$ & $85.33+1.120 \mathrm{X}$ \\
\hline Peel weight (g) & 0.746 & $*$ & $26.76+0.017 X$ \\
\hline Peel proportion $(\%, w / w)^{y}$ & -0.885 & ** & $32.01-0.022 \mathrm{X}$ \\
\hline \multicolumn{4}{|l|}{ Juice } \\
\hline Content $(\%, \mathrm{w} / \mathrm{w})^{\mathrm{x}}$ & 0.676 & * & $45.93+0.036 \mathrm{X}$ \\
\hline Acidity (mg/fruit) & 0.155 & NS & $572.75+0.505 X$ \\
\hline Acidity (A) (\%) & -0.868 & ** & $1.50-0.002 \mathrm{X}$ \\
\hline $\mathrm{SSC}^{\mathrm{w}}\left({ }^{\circ} \mathrm{Brix}\right)$ & 0.422 & NS & $10.35+0.004 \mathrm{X}$ \\
\hline SSC : A & 0.879 & ** & $6.92+0.016 \mathrm{X}$ \\
\hline
\end{tabular}

${ }^{\mathrm{z} V a l u e s}$ correspond to Date 1 of treatment (1988).

yProportion of peel weight relative to fruit weight.

${ }^{x}$ Proportion of juice weight relative to fruit weight.

${ }^{\text {wSSC }}=$ soluble solids concentration.

ws, *** Nonsignificant or significant at $P \leq 0.05$ or 0.01 , respectively. 
Table 3. Effect of 2,4-DP concentration on peel characteristics and puffiness of 'Owari Satsuma' mandarin fruit at harvest. ${ }^{z}$

\begin{tabular}{|c|c|c|c|c|}
\hline \multirow{3}{*}{$\begin{array}{l}\text { Concn } \\
\left(\mathrm{mg} \cdot \text { liter }^{-1}\right)\end{array}$} & \multicolumn{2}{|c|}{ Peel } & \multirow{2}{*}{\multicolumn{2}{|c|}{$\begin{array}{c}\text { Puffiness incidence (\%) } \\
\text { Examination }\end{array}$}} \\
\hline & \multirow{2}{*}{$\begin{array}{l}\text { Thickness } \\
(\mathrm{mm})\end{array}$} & \multirow{2}{*}{$\begin{array}{l}\text { Firmness } \\
\text { (g) }\end{array}$} & & \\
\hline & & & External & Internal \\
\hline 0 & 3.66 & 793 & 56.0 & 80.0 \\
\hline 25 & 3.79 & 823 & 20.7 & 82.5 \\
\hline 50 & 3.74 & 845 & 15.1 & 72.5 \\
\hline$r^{\mathbf{y}}$ & 0.414 & 0.918 & -0.966 & -0.124 \\
\hline Significance & NS & $* *$ & $* *$ & NS \\
\hline
\end{tabular}

${ }^{2}$ Average values for fruit treated on Date 1 (1988).

'Linear regression coefficient.

Ns, ** Nonsignificant or significant at $P \leq 0.01$, respectively.

sent with 2,4-DP because of the time of application. In contrast to results reported for other synthetic auxins such as 2,4,5-T (Guardiola et al., 1993), the 2,4-DP application appears to have an immediate effect on fruitlet growth (Agustí et al., 1994). The determinant of the final effect is the balance between the early depressive and the subsequent stimulator effects elicited by most auxins (Guardiola et al., 1988). Fruit treated with 2,4-DP grew larger than those treated with other synthetic auxins (Agustí and Almela, 1991; Agustí et al., 1991b). Because 2,4-DP did not affect fruit count but increased fruit diameter, the effects of fruit competition and fruit growth were separate.

This direct fruit growth stimulation was primarily manifested as an increase in fruit segments, and in turn, it produced an increase in juice percentage and a decrease in peel percentage. Furthermore, the decreased peel percentage was accompanied by improved external fruit quality, i.e., firmer peel and reduced puffy appearance.

Auxin-stimulated pulp growth demonstrated how treatment date affects its efficacy. After physiological drop, fruit development is characterized by an almost complete cessation of cell division, continuing cell enlargement, and juice accumulation (Bain, 1958). At this stage, applying auxin on 'Nova' mandarin stimulated cell expansion, especially of juice vesicles (Agustít al., 1994). Cell expansion is the major contributor to mature fruit size (Guardiola et al., 1993). This growth increased vesicle capacity for juice accumulation; therefore, fruit grew faster. Delaying treatment until cell expansion diminished or ceased made treatment less effective (Agustí and Almela, 1991; Guardiola and Lázaro, 1987).

\section{Literature Cited}

Agustí, M, and V. Almela. 1984. Mejora de la calidad del fruto de la mandarina Satsuma. Bco. Santander, Madrid, Spain.

Agustí, M. and V. Almela. 1991. Aplicación de fitorreguladores en citricultura. AEDOS, Barcelona, Spain.

Agustí, M., V. Almela, M. Aznar, J. Pons, and M. El-Otmani. 1994. The use of 2,4-DP to improve fruit size in citrus. Proc. Intl. Soc. Citricult. (In press.)

Agustí, M., V. Almela, and J. Pons. 1991a. Efecto del 2,4-DP (ácido 2,4-diclorofenoxipropiónico) sobre el desarrollo y tamaño final del fruto de la mandarina Clementina fina (Citrus reticulata Blanco). Levante Agrícola 307/308:4-12.

Agustí, M., V. Almela, and J. Pons. 1991b. Tratamientos para aumentar el tamaño del fruto en los agrios. Generalitat Valenciana, Valencia, Spain.

Almela, V., M. El-Otmani, J. Pons, and M. Agustí. 1991. Aumento del tarnaño final del fruto en mandarins mediante la aplicación de 2,4-DP. Valoración agronómica. Levante Agrícola 309/ 310:86-94.

Bain, J.M. 1958. Morphological, anatomical and physiological changes in the developing fruit of the Valencia orange (Citrus sinensis (L.) Osbeck). Austral. J. Bot. 6:1-24.

El-Zeftawi, B.M. 1976. Effects of ethephon and 2,4,5-T on fruit size, rind pigment and alternate bearing of Imperial mandarin. Scientia Hort. 5:315-320.

Guardiola, J.L., M. Agustí, F. García-Marí, and V. Almela. 1982. The regulation of fruit size in citrus by tree factors. 21 st Intl. Hort. Congr., Hamburg, Germany. 1:1363. (Abstr.)

Guardiola, J.L., V. Almela, and M.T. Barrés. 1988. Dust effect of auxins on fruit growth in Satsuma mandarin. Scientia Hort. 34:229-237.

Guardiola, J.L., M.T. Barrés, C. Albert, and A. García-Luis. 1993. Effects of exogenous growth regulators on fruit development in Citrus unshiu. Ann. Bot. 71: 169-176.

Guardiola, J.L. and E. Lázaro. 1987. The effect of synthetic auxins on fruit growth and anatomical development in Satsuma mandarin. Scientia Hort. 31:119-130.

Hirose, K. 1981. Development of chemical thinners for commercial use for Satsuma mandarin in Japan. Proc, Intl. Soc. Citricult. 1:256-260.

Kamuro, Y. and K. Hirai. 1981. Physiological activity of ethylchlozate: Fruit thinning and maturity accelerating effects for citrus. Proc. Intl. Soc. Citricult. 1:260-263.

Lewin, I.J. and S.P. Monselise. 1976. Further studies on the reduction of seeds in mandarins by NAA sprays. Scientia Hort. 4:229-234.

Morioka, S. and S. Yahata. 1989. Influence of fruit load just before fruit thinning on fruit size, yield and flower bud formation in Satsuma mandarin. J. Jpn. Hort. Sci. 58:97-103.

Ortolá, A.G., C. Monerri, and J.L. Guardiola. 1991. The use of naphthalene acetic acid as a fruit growth enhancer in Satsuma mandarin: A comparison with the fruit thinning effect. Scientia Hort. 47:15-25.

Suzuki, K. and K. Hirose. 1977. Effect of J-455 on thinning and fruit quality of Satsuma mandarin. Autumn Mtg. Jpn. Soc. Hort. Sci. p. 34-35. (Abstr.)

Vanniere, H. and P. Arcuset. 1989. Amélioration du calibres des clémentines en Corse par l'emploi du dichlorprop. Fruits 44:393-400.

Zaragoza, S., I. Trenor, and E. Alonso. 1990. Influencia del aclareo sobre el calibre de los frutos de la Satsuma Clausellina. Actas I Congr. Ibér. Ciencias Hort. 3:113-118. 